UDC 72:[378.6:791/792(497.11 Beograd)

https://doi.org/10.18485/ms_zmslu.2021.49.15

Прегледни научни рад

Соња Р. Јанков*

\title{
ФРИЗ КАО УЏБЕНИК: ДОПРИНОС ЖИВОЈИНА ПАВЛОВИТА АРХИТЕКТУРИ ЈУГОСЛОВЕНСКОГ МОДЕРНИЗМА
}

\begin{abstract}
САЖЕТАК: У згради Факултета драмских уметности на Новом Београду, налази се специфичан фриз компонован од различитих репродукција којима недостају легенде и описи, али се зна да је аутор фриза Живојин Павловић, југословенски режисер црног таласа, прозаиста, есејиста и факултетски професор. Овај рад је реконструкција и анализа садржаја тих репродукција, као и функције целог фриза у згради Факултета. У раду се дају основни подаци о архитектури зграде Факултета драмских уметности која је својим обликом и функцијом директно утицала на облик фриза, затим се приступа фризу као декоративном и дидактичком архитектонском елементу из перспективе историје уметности. Централни део рада је посвећен анализи садржаја фриза, у зависности од простора различитих функција кроз које се простире. Анализа обухвата садржај одабраних плоча, њихов међусобни однос и однос према историји дисциплина које приказују. У раду се закључује да је фриз Живојина Павловића у згради Факултета драмских уметности значајан допринос историји фриза и да као дидактичко средство претвара архитектуру у апарат за учење о филму и другим дисциплинама заступљеним у програму ФДУ.
\end{abstract}

КљУЧНЕ РЕЧИ: фриз, Живојин Павловић, југословенска архитектура, Факултет драмских уметности.

\section{Увод}

Зграда Факултета драмских уметности (у наставку: ФДУ) једини је реализовани део кампуса Универзитета уметности у Београду за који су ауторски тим у саставу Александар Стјепановић, Божидар Јанковић и Михаило Наслас израдили пројекат 1964. године. Предвиђена као део Академије за позориште, филм, радио и телевизију,

* Универзитет уметности у Београду, jankovsonja@gmail.com

** Захваљујем овом приликом професорки Милени Драгићевић Шешић на разговорима о фризу у ФДУ, професору Николи Шуици на анализи фризова Вилијема Кентриџа (William Kentridge) у контексту покретних слика и Милану Ђорђевићу на уступљеним фотографијама. 
зграда је требало да буде део констелације којој би припадале академије за музику, ликовне и примењене уметности, као и аудиторијуми за извођење драме, филма, музике и балета. Завршена 1975. године (биоскопска сала 1980), зграда је карактеристична по издуженом, структуралном облику, аксијалном низању просторија на три нивоа, масивним површинама у опеци, строгим линијама изложене армиранобетонске конструкције и разиграних бетонских лула, венаца и пергола, те великим стакленим површинама и аулом, осветљеном кроз кров од млечних делимично транспарентних призми (ЈовАновић 2019: 48).

Кроз зграду се простире специфичан фриз ${ }^{1}$ који чине плоче са одштампаним црно-белим репродукцијама из историје филма, фотографије, позоришта, књижевности, ликовне уметности, писања, штампарства и изума за летење, поређане изнад врата, школских табли или испод таванице одређених просторија и ходника. Сви елементи фриза, ${ }^{2}$ иако често врло удаљени једни од других, естетски и пропорционално су складни и обухватају целину зграде, те им се у раду приступа као јединственом просторно-визуелном средству приповедања чија је сврха преношење знања. Фриз је уредио Живојин Павловић по завршетку зграде, у периоду када је имао позицију референта за учила, након уклањања са позиције доцента на предмету Филмска режија. Иако је Павловић дипломирао декоративно сликарство на Академији примењених уметности у Београду, цртањем и сликањем је врло рано престао да се бави, те су на фриз највећи утицај извршила његова промишљања филма и прозног приповедања.

Како су плоче фриза искључиво визуелне и без пропратних легенди о изворима и садржају репродукција, овај рад представља истраживање о садржају, композицији и односу фриза према згради за коју је састављен, са циљем његовог истицања као значајног доприноса уметности створене за архитектуру југословенског модернизма. Услед разноликости садржаја који потиче из више дисциплина, закључили смо да репродукције не потичу из једне публикације/лектире/уџбеника, те да је потребно реконструисати шта свака плоча представља, што је захтевало методологију која одговара конкретно овом фризу. Како многе плоче не садрже целе репродукциje, није било могуће коришћење алгоритама за претраживање дигитализованих слика. Уочавањем да се сигнатура Poyet појављује на неколико репродукованих гравура, истраживање се окренуло стваралаштву Луја Појета (Louis Poyet), а тиме и дигитализованим архивама часописа La Nature и Scientific American за које је Појет редовно израђивао илустрације. Поред тога, реконструкцији садржаја фриза је помогло истраживање у домену историје фотографских и филмских камера, позоришта, ликовне уметности, прототелевизијских апарата, док су за налажење извора репродукција које садрже текстове помогли транскрипција и текстуално претраживање.

${ }^{1}$ Није сачуван податак да ли је било планирано да све академије у склопу Универзитета уметности имају фризове у својим ентеријерима.

2 Иако се у раду сви елементи посматрају као део једног фриза, сваки анализирани сегмент се описује као „фриз”, а не као „део фриза”, да би се омогућило лакше читање. 
ФРИЗ КАО УЏБЕНИК: ДОПРИНОС ЖИВОЈИНА ПАВЛОВИТА АРХИТЕКТУРИ ЈУГОСЛОВЕНСКОГ...

\section{Павловићев фриз у односу на фриз кроз историју уметности}

Фриз је декоративан архитектонски елемент чији је најбоље сачувани антички пример део Партенона, светилишта богиње Атине, исклесан између 442. и 438. п. н. е. у јонском стилу. Партенонски фриз је дуг 160 м и предмет је различитих тумачења jep се не може сагледати до детаља пошто је постављен на висину од око 12 м, видљив тек под углом од 45 степени (или оштријим), заклоњен стубовима и без директног осветљења. Фриз је стога могуће видети „само као серију дугачких панела који су са обе стране урамљени стубовима" (MARCONI 2009: 162). Иако у својој форми линеаран и заокружен, начином на који је постављен иза стубова, фриз на Партенону губи континуитет нарације. Оваква позиција и фрагментисаност фриза ангажују гледаоца да „размишља о односу између статичности и кретања” (ØSTERMARK-JOHANSEN 2009: 20).

Својом полускривеношћу, фриз на Партенону активно ангажује посетиоца да се креће и „ствара оно што види својим позицијама, чиме процес гледања фриза постаје процес континуираног стварања нових погледа” (Osвorne 1987: 99). Положај фриза „присиљава посетиоце да се крећу напред, неизоставно стварајући поворку” (OsBorne 1987: 102), чиме се осигурава трајност процесије која је на њему приказана. Фриз на тај начин постаје својеврсни апарат анимације који је у исто време и огледало, приказујући поворку у славу Атине и иницирајући је у садашњем времену.

Буркхард Фер (Burkhard Fehr) сматра да је фриз на Партенону средство учења о једнакости, дисциплини и колективитету демократског друштва након увођења радикалних демократских реформи 462. п. н. е. По Феровом мишљењу, фриз представља кључни преокрет по којем аристократско порекло више није било довољно да би неко био у коњици или на било којем положају; постало је потребно да његов етос буде узор свим грађанима и да има потврду/одобрење народа (2011: 65-66). Из тог разлога су млади људи приступали великом броју такмичарских активности како би се доказали, и фриз приказује како више није довољно живети само по мерама божанског устројења, него и по мерама демократског друштва.

Како ће се видети у наставку рада, фриз Живојина Павловића има неколико заједничких особина са фризом на Партенону. Осим што је такође примарно дидактичан, Павловићев фриз ангажује гледаоца/студента да размишља о односу између статичности и кретања како је велик број репродукција посвећен техничком развоју преношења покретне слике. Као и фриз на Партенону, фриз у згради ФДУ омогућава младим људима да сагледају достигнућа друштва којег су део и да се изборе за своје место у дисциплини коју су одабрали. Он је део југословенске архитектуре која је имала за циљ конституисање новог југословенског човека и монументализацију југословенских вредности - ослобођења, прогреса, аутентичности, децентрализације, друштвене авангарде и политичког лидерства, плуралности, отворености и демократичности (IgNJATOVIĆ 2012: 692). Он такође подстиче да се обиђе и/или користи цела зграда и тиме неминовно постане делом колективитета који је генерацијама користио 
зграду и доприносио култури, што је блиско Павловићевом приступу простору у филмовима и прози, у којима је простор увек динамизован кретањем јунака (ЈовАновић 2017: 314).

Павловић је сматрао да је филм средство преко којег млади „развијају своја осећаға йравих вреgносии" (2010 [1956]: 23, истицање у оригиналу) и сматрао је да би већ основна школа морала да се ангажује да ђацима изгради критичко-аналитички начин размишљања управо путем филма. Фриз се у овом контексту појављује као једно од дидактичких средстава која служе том циљу. Попут Павловићевог предлога програма за наставни предмет о филму у основној школи, фриз у згради ФДУ обухвата „прве справе које анимирају покрет, прве неусавршене покушаје фиксирања разних фаза покрета, Едисонов кинетоскоп (биоскоп за једног гледаоца), Лемијеров епохални проналазак и прве филмове браће Лимијер" (2010 [1957]: 33), ${ }^{3}$ као и сцене из историје позоришта, штампарства и машина за летење. Овакав однос према фризу, близак је Павловићевој поетици коју одликују „полифонија, поливалентна форма, транстекстуалност у различитим видовима, натурализација говора и слика, вишеструка фокализација, тематско и просторно јединство, фреквентност ликова и умножавање њихових функција" (Вујисић 2015: 147). Њу такође одликује и цитирање једне врсте уметности у оквиру друге, тако да уметнички материјал „може да представља уметничко дело исте или различите уметности, као и било која чињеница културе” (КолАРИЋ 2017: 25), што је демонстрирано управо у фризу.

\section{Реконструкција садржаја фриза}

По својој структури, Павловићев фриз задржава антички модел да прати контуру грађевине за коју је створен, али како је архитектонска форма зграде ФДУ много другачија од правоугаоног Партенона, фриз нема заокружен линеаран континуитет. Зграда ФДУ је специфична по томе што су на њој видљиви утицаји структурализма који је у архитектуру унео идеје о међуодносу и еволутивном расту, развоју и трансформацији (Стојиљковић 2017: 20) и тежњу ка флексибилности простора путем отворених решења (ibid.: 315). На њој су такође видљиви утицаји тада савремене архитектуре из Западног Берлина, Варшаве и Прага, које су аутори студијски обишли пре израде пројекта да би видели најновије тенденције у концепцији зграда уметничких академија. Ови утицаји су резултирали тиме да су све зграде академија у Универзитету уметности биле замишљене као подуже, растуће структуре, формиране „адицијом функционалних целина у трактове, повезане коридорима - затвореним

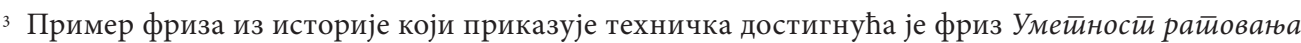
на Дуждевој палати у Урбину. Седамдесет и две рељефне плоче фриза, израђене од краја XV века до 1756. године, приказују бројне ратне машине, као и ратне и политичке симболе, инжињерске нацрте и наутичке симболе чији је редослед немогуће било реконструисати јер су рељефи временом отпадали и били склањани у унутрашњост зграде како би били сачувани (BARATIN et al.). 
ФРИЗ КАО УЏБЕНИК: ДОПРИНОС ЖИВОЈИНА ПАВЛОВИТА АРХИТЕКТУРИ ЈУГОСЛОВЕНСКОГ...

и отвореним" (ЈовАновић 2019: 47) који би умрежили све функционалне јединице у јединствену урбану целину. У њима је тако најављена значајна промена која се у архитектури југословенског модернизма десила тек од средине 1970-их и то примарно на објектима културе. У том периоду се комплексност функције објеката рефлектује на њихову просторну композицију, коју почињу да карактеришу диференцијација целина, динамика волумена различитих облика, размера и висина (ĐURĐEV, MOMIROV 2014: 156). Објекат културе „престаје да буде последица реализације одређених изражајних облика, поставши просторна акција настала као резултат интеграције простора објекта и његовог садржаја или догађаја којима је намењен” (ЛујАК 2012: 5).

Карактеристике зграде су исфрагментисале фриз, те он својом композицијом и садржајем донекле подсећа на уметничку инсталацију Човек, машина и йокрет̄ Ричарда Хамилтона (Richard Hamilton) из 1955. коју чини 176 слободно распоређених фотографских паноа преузетих из историје техничких изума. За разлику од ње, фриз у згради ФДУ је директно повезан са зградом у којој се налази и не треба га посматрати одвојено од ње и њене функције, као што је то случај и са бројним муралима, таписеријама, теписима, мозаицима, намештајем и осветљењем дизајнираним специфично само за зграду Савезног извршног већа на Новом Београду (завршена 1964). Фриз у згради ФДУ стога није ауйономан уметнички пројекат, али управо захваљујући томе, могуће је анализирати садржај и наратив фриза.

\section{Фриз у јавним просторима у згради ФДУ}

Фриз се у јавним просторима зграде ФДУ простире кроз заједничко предворје позоришне и биоскопске сале, испод светларника степеништа и у ходницима. Изнад ходника који повезује аулу зграде Факултета са предворјем сала, налази се илустра-

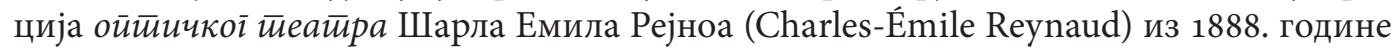
(сл. 1). ${ }^{4}$ Овај изум, који се сматра претечом филма, спаја позориште и оптичку пројекцију, тако да се постављањем њега на овом месту одлично најављује остатак простора, то јест биоскопска и позоришна сала. За анимиране пројекције са ойииччкой $\bar{u} е a \bar{u} p a$, Рејно је ручно израђивао 300 до 700 слика на транспарентним тракама од желатина и потом их анимирао механизмом који је конструисао. Анимиране представе које је називао светилосним йанйомимама (Pantomimes Lumineuses) пројектовао је од 1892. до 190о. када је „сцену” преузео синемайойраф браће Лимијер (Lumière).

Са десне стране, како се прилази камерној сцени „Мата Милошевић”, постављене су две репродукције из историје књижевности. Прво се наилази на илустрацију Пола Гистава Дореа (Paul Gustav Doré) која приказује Дантеа (Dante Alighieri) док клечи пред анђелом који превози душе у чистилиште, према певању из Божансиивене комеguје. Поред њега је Вергилије, његов узор, учитељ и водич. Овим поступком

4 За више илустрација и података о изворима репродукција, вид. архиву насталу током истраживања: <https://sonjajankov.wordpress.com/2020/05/14/research-material/>. 

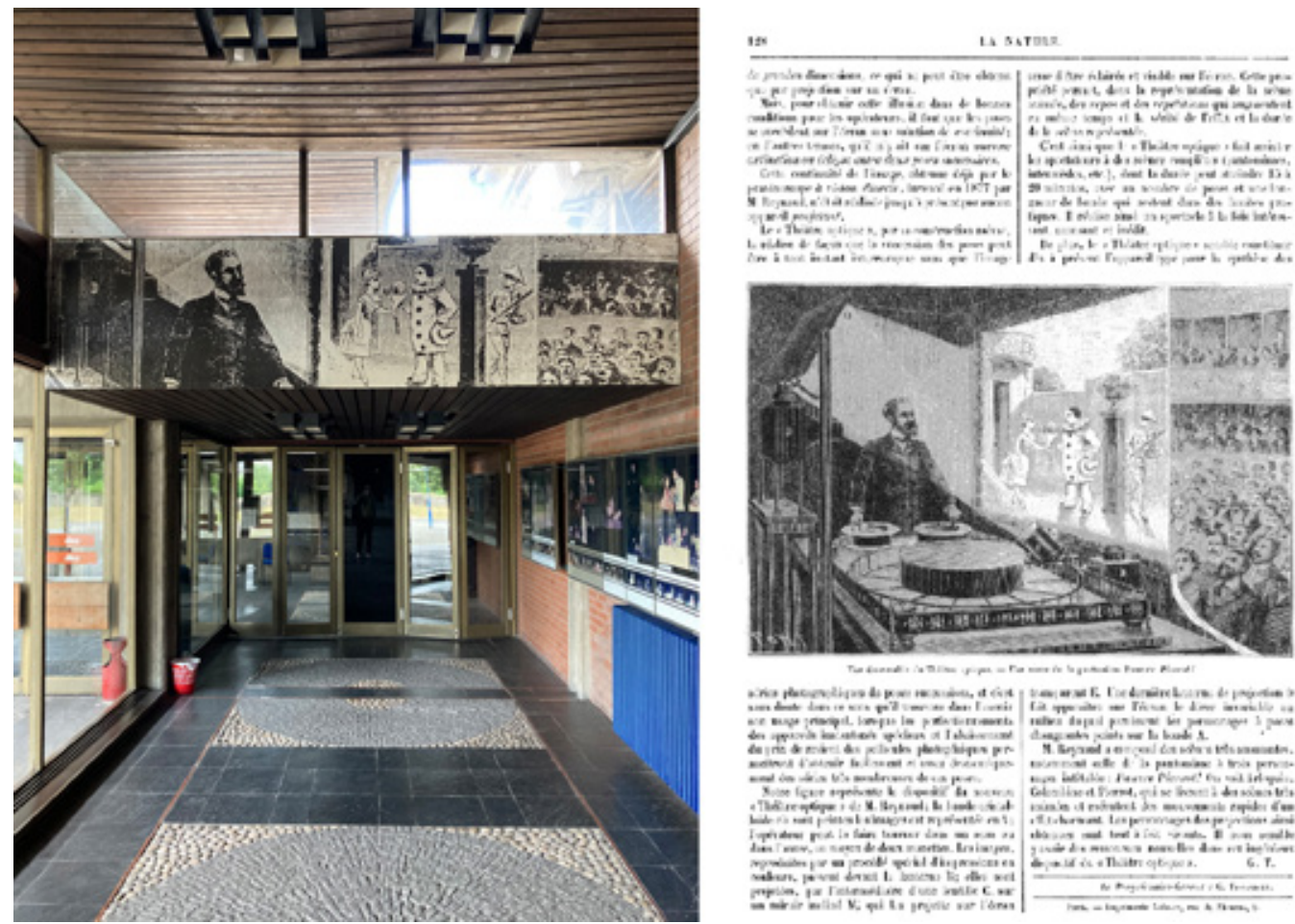

Сл. 1. (Лево): улаз у предворје које повезује биоскопску и позоришну салу (фотографија:

Милан Ђорђевић);

(Десно): примарни извор репродукције. Аутор илустрације: Луј Појет, представљени изум: оптички театар (Théâtre Optique) - проналазак Шарла Емила Рејноа из 1888, први пут објављена уз чланак „Оптички театар М. Рејноа” Гастона Тисандјеа (Gaston Tissandier), La Nature, 6p. 999, 25. јул 1892.

се повезује функција предворја сала са чистилиштем, као предворјем раја.5 Поред ове репродукције, налази се још једна Дореова гравура, израђена за Изіубљени рај Џона Милтона (John Milton), која приказује анђеле како победнички свирају у своје

5 На примеру фриза Генеза на византијској Цркви Свете Софије изграђеној у Трапезунтском царству у XIII веку, Ентони Истмонд (Antony Eastmond) указује како положај фриза и распоред плоча стварају његово значење. Приказујући само одабране сцене из Генезе неуобичајеним редоследом здесна налево, фриз на Светој Софији даје фрагментаран и мизоген наратив који почиње Евиним грехом и завршава се братоубиством. Анализом путање којом верник мора да прође да би ушао у цркву, Истмонд долази до закључка да фриз приказује грех и тиме што је постављен на фасади служи као граница између „екстеријера и ентеријера, од греха ка спасењу које нуди црква“ (1999: 226). Слично можемо посматрати и постављање сцене из Божанстивене комеgије на овом специфичном месту у згради ФдУ. Како је извођење завршног рада на позорници врхунац и круна драмског образовања које Факултет нуди, репродукцијом из Божансйвене комеguје се предворје у салу очитава као специфично чистилиште које води у рај, то јест које резултира катарзом кроз изведени рад. 




Сл. 2. Део фриза изнад светларника степеништа (фотографија: Милан Ђорђевић)

трубе. Изнад улаза у биоскопску салу, постављена је илустрација „природне машине за летење” непознатог аутора из 1865. који предлаже да се по десет орлова упрегне у носећу конструкцију и тиме лети. Постављањем, наспрам Дореовог и Милтоновог анђела, овог можда најнезграпнијег и најбезобзирнијег изума за летење у којем се отворено орлови сматрају инфериорним бићима које треба експлоатисати, указује се на сталне тежње човека да се уздиже по сваку цену.

У светларнику степеништа постављен је фриз од пет плоча и све се фокусирају на развој камера у XIX веку (сл. 2). Прва у низу представља Едисонов кинетиоской из 1891, рани апарат за покретне слике које је могла да гледа само једна особа, с обзиром на то да су се слике налазиле у апарату и у њему биле анимиране. Кинетоскоп је поставио стандард за израду покретних слика који је трајао до открића видеа, а који се базирао на брзом сукцесивном смењивању статичних слика. Поред њега је синемайоіраф браће Лимијер из 1895. који је функционисао као камера, израђивач фотографија и пројектор, у зависности од тога како се саставе сочива и коморе. 
У центру фриза се налази кружна форма плоче на којој су хронофотографије настале фотографском пушком коју је 1882. патентирао Етјен Жил Маре (Étienne-Jules Marey). Мареов изум је могао да сними 12 фотографија у секунди, на истој плочи, што је био почетак његових истраживања о покрету. Ова репродукција изгледа као центар композиције фриза око које се симетрично ређају све плоче. Након ње је гравура која приказује претечу блица, хемијску реакцију која је стварала вештачко осветљење у фотографским студијима. За ту сврху се најчешће користио магнезијум, али и други метали у комбинацији са оксидансом на бази хлора. Последња у низу је камера са аутоматским мењачем плоча коју је 1895. дизајнирао Житон де Жироди (Guitton de Giraudy). Ова камера је имала у себи два механизма, од којих је један контролисао бленду, а други мењао плоче.

Од степеништа води ходник у приземном делу у којем су смештени студији за филм. Изнад самог почетка ходника, на прилазу из кафеа, налази се велика репродукција Ерсове (W. O. Ayres) нове летеће машине из 1885. коју су покретали компресован ваздух и енергија коју је путник/пилот производио окрећући педале. Ово је уједно друга слика из историје летења која је заступљена у фризу. Изнад улаза у зборницу је део фриза који се ломи под углом од 90 степени, пратећи контуру ходника, и представља йелеоской Франсоа Дисоа (François Dussaud) из 1898. Телеоскоп је путем електричних импулса преносио слику од камере до пројектора и био претеча телевизије, то јест преноса уживо. Наспрам ходника на спрату где су кабинети, постављен је детаљ из серије Кою у йокретиу Едварда Мајбриџа (Eadweard Muybridge), сегмент „аутоматских електрофотографија” које је начинио 1878. и које су имале значајну улогу у каснијем развоју покретних слика и технике за њихово бележење.

\section{Фриз у просторима учења}

Фризови у учионицама су постављени изнад школских табли и највећим делом се фокусирају на историју филма и позоришта. У једној учионици фриз чине три илустрације које је Луј Појет урадио за чланке у француском недељном магазину $L a$ Nature. Са десне стране је приказан йраксиноской, ранији изум Емила Рејноа из 1877. године, апарат за анимацију који је био следбеник зоотропа и унапређен у односу на њега увођењем огледала која су омогућавала мању дисторзију слике. У средини jе џепна камера коју је 190о. пласирао Леон Гомон (Léon Gaumont) као аматерски синематограф. У новој малој камери је филм могао да се мења по дневном светлу и могла је да сними укупно 500 слика. Са десне стране је приказ типичног фотографског атељеа са природним светлом.

У учионицама, Павловић примењује и „концентричну” композицију, коју је применио и у светларнику степеништа. Поред симетричног распореда репродукција у односу на централни приказ, концентричност композиције у учионицама је постигнута и сечењем репродукција. У једној учионици, централно место припада реконструкцији Шекспировог позоришта (the Globe) коју је према архивским налазима и 
ФРИЗ КАО УЏБЕНИК: ДОПРИНОС ЖИВОЈИНА ПАВЛОВИТА АРХИТЕКТУРИ ЈУГОСЛОВЕНСКОГ...

различитим записима реализовао Валтер Хоџс (Walter Hodges). Симетрично са обе стране се нижу античке позоришне маске и неокласицистичке гравуре које приказују смрт Офелије и Хамлетову борбу да она добије достојанствену сахрану, чиме се заокружује поглед у историју позоришта у овом делу.

У другој учионици, у центру је репродукција рекламе компаније Scovill из 1883. која приказује жену за камером, а не испред ње. Реклама је промовисала камере са новим желатинским плочама које су замениле дотадашњи процес израде фотографије у „мокром” колодијумском процесу, чиме је камера постала приступачнија тадашњим и потенцијалним аматерским фотографима. Одабиром ове рекламе, Павловић не само што указује и на историјски тренутак када је фотографска камера постала приступачнија за коришћење, него и ставља жену за камером у центар композиције, указујући на улогу развоја технике у родној равноправности.

\section{Фриз у библиотеци}

Фриз у библиотеци има највише сличности са класичним фризом у смислу да је у континуитету линеаран, без прекида. Укупно 23 плоче приказују историју система комуникације, писања и штампања од најстаријих цивилизација, преко открића механизама за штампање до еманципације жена у канцеларијским пословима. Прикази нису хронолошки поређани, али се у фризу ипак може препознати главни наративни ток.

За прву плочу је симболично одабрано прво слово, илуминативно украшено иницијално слово списа Le Livre de Matheolus из 1492. Последња плоча је репродукција рекламе за прву писаћу машину коју је 1872. патентирао Кристофер Лејтам Шоулс (Christopher Latham Sholes), а коју на реклами користи његова ћерка. Како је куцање на машини слично свирању клавира, писаћа машина и слични изуми су отворили могућност женама да добијају послове у канцеларијама, те ова плоча представља и кратак поглед на историју еманципације жена.

Од древних система комуникације, фриз приказује еволуцију египатског система писања од хијероглифског, преко хиератског, до демотичког (плоча 2), као и систем кийy (quipu) који су користиле Инке (плоча 5) и путем којег се преносила информација комбинацијом боје канапа, броја чворова на њему и њиховом међусобном удаљеношћу. Остали прикази на фризу се могу поделити у три групе: историју писања, историју штампарских проналазака и историју књиге.

Историја писања је хронолошки приказана кроз шест репродукција које нису поређане у континуитету, него су помешане са приказима из других области. Најстарија је графика Албрехта Дирера (Albrecht Dürer) из 1511. која приказује Светог Јеронима, преводиоца Библије и заштитника учењака, у његовој радној ћелији (плоча 4). Следе четири примера калиграфије (плоче 7, 9, 18, 20), закључно са калиграфским цртежом витеза Мануела де Фигеиреда (Manoel de Figueiredo) из 1722, као и упутство за конструкцију римских капиталних слова која су у исто време и предмет далеке историје и савремене типографије. 
Историја штампарства је приказана путем шест плоча, од којих се три фокусирају на XVI век, а преостале три на изуме XIX века. Најстарија репродукција је Дирерова графика Шйамйарска йреса из 1520. (плоча 19). Тематика прављења папира je приказана одабиром репродукције графике Јоста Амана (Jost Amman) из 1568. (плоча 16), а ту је и портрет Јохана Гутенберга (Johann Gutenberg), проналазача покретне пресе (плоча 12). Од изума XIX века, одабрани су класични штампач Џорџа Клајмера (George Clymer) из 1828. којим је страница новина могла да се штампа у једном тиску (плоча 14), као и једноцилиндрична штампарска машина за веће тираже коју је дизајнирао Иполит Маринони (Hippolyte Marinoni) 1850. (плоча 8). Најновији штампарски изум на фризу је минијатурни, џепни штампач Полиіллой из 1878. (плоча 17), чиме се указује на развој технике у смеру тога да свако има свој апарат који се лако може носити са собом.

Историја књиге не почиње Гутенберговом Библијом, него књигом псалама коју су његови сарадници одштампали након покретања самосталне штампарске праксе. Mainz Psalter који је 1457. одштампан код њих, прва је књига штампана у три боје и две величине фонта, а садржала је и друге иновације попут године штампања и колофона (логотипа) издавача који се и данас користе (плоча 15). Од књига из XVI века, ту cy Chronicon Abbatis Urspergen из 1515. (плоча 21), стразбуршка књижица из исте године која приказује лакрдијаша Тила Ојленшпигела (Till Eulenspiegel), лика из не-

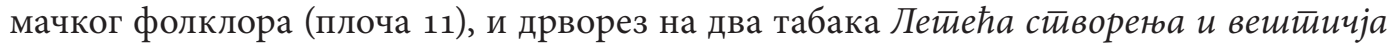
колиба Ханса Вајдица (Hans Weiditz) из 1532. (плоча 10). Најновија заступљена књига је збирка песама Вилијема Шекспира из 1893, одабиром странице песме „Венера и Адонис" (плоча 6). Фриз укључује још један запис о љубави, у виду ранохришћанске надгробне плоче из VII века (плоча 13) са натписом о младом пару који почива испод ње. Ова плоча је постављена између портрета Гутенберга и штампача Џорџа Клајмера из 1828, чиме се указује на стремљење човека да створи вишевековну трајност записа.

Линеарност фриза у библиотеци отворила је Павловићу могућност за стварање наративног тока који је приметан упркос нехронолошким приказима историје онога што библиотека представља. Од првог слова, до еманципације жена, фриз је збирка пажљиво одабраних проналазака и пажљиво одабраних репродукција које их приказују. Упливом писаних садржаја, овај део фриза излази из домена доминантно визуелног и као такав се надовезује на функцију и садржај простора у којем се налази.

\section{Закључак}

Фризом у згради ФДУ, Павловић антички архитектонски елемент прилагођава архитектури СФРЈ, и обликује га као учило о почецима филма, позоришта, телевизије - дисциплина којима се студенти уче на Факултету. Од мноштва илустрација технолошких изума који су унапредили историју фотографије и филма, Павловић је за фриз одабрао оне које приказују нов однос између човека и камере, као што је мобилност 
ФРИЗ КАО УЏБЕНИК: ДОПРИНОС ЖИВОЈИНА ПАВЛОВИЋА АРХИТЕКТУРИ ЈУГОСЛОВЕНСКОГ...

захваљујући мањим димензијама апарата или лакша употреба која је стварање филма учинила приступачнијим свима. Фокусирањем на ране проналаске, као што је и штампање књига и први концепти летелица, Павловић указује на оне прекретне изуме који су отворили потпуно нове могућности за делање, незамисливе до тада.

Павловић је за фриз одабрао репродукције естетски врхунских илустрација које су израдили Луј Појет, Албрехт Дирер, Пол Гистав Доре и водећи калиграфи свог времена. Све оне су постављене у промишљеном односу према простору и различитим функцијама које има, те је фриз специфичан ауторски допринос дидактичким средствима, уметности премењеној на архитектуру југословенског модернизма и форми фриза у XX веку.

\section{ЛИТЕРАТУРА}

Baratin, Laura, Monica Giuliano, Giovanni Checcucci. "The Art of War Frieze in Urbino: A Blend of Virtual Reconstruction and Scientific Accuracy." proceeding from the $3 D$-ARCH 2013 ${ }_{3} D$ Virtual Reconstruction and Visualization of Complex Architectures, 25 - 26 February 2013, Trento, Italy. International Archives of the Photogrammetry, Remote Sensing and Spatial Information Sciences. volume XL-5/W1: 2013, 9-13.

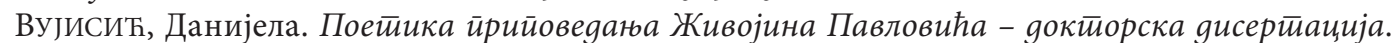
Београд, Филолошки факултет (VUISIĆ, Danijela. Poetika pripovedanja Živojina Pavlovića - doktorska disertacija. Beograd, Filološki fakultet), 2015.

ĐurĐEv, Mila, Maja Momirov. „Programsko prostorne i morfološke karakteristike objekata domova kulture i kulturnih centara u Republici Srbiji.” U: DINUlović, Radivoje, Dragana Konstantinović, Miljana Zeković (ur.). Arhitektura objekata domova kulture u Republici Srbiji. Novi Sad: Fakultet tehničkih nauka, 2014, 125-160.

Eastmond, Antony. "Narratives of the Fall: Structure and Meaning in the Genesis Frieze at Hagia Sophia, Trebizond." Dumbarton Oaks Papers 53 (1999): 219-236.

Ignjatović, Aleksandar. „Tranzicije i reforme: arhitektura u Srbiji 1952-1980.” U: ŠUVAKOVIĆ, Miško (ur.). Istorija umetnosti u Srbiji XX vek. Tom 2, Realizmi i modernizmi oko hladnog rata. Beograd: Orion art, Katedra za muzikologiju Fakulteta muzičke umetnosti, 2012, 689-710.

JovAnović, Jelica. „Arhitekta Aleksandar Stjepanović - infrastruktura društva: stanovanje i prateće funkcije, objekti dečje zaštite, školstva i visokog obrazovanja." U: IVANOVIĆ VOJVODIĆ, Jelena, Danica Jovović Prodanović, Ružica Sarić (ur.). Pozitivno i aktivno: 14. Beogradska internacionalna nedelja arhitekture. Beograd: Društvo arhitekata Beograda, Kulturni centar Beograda, 2019, 36-58.

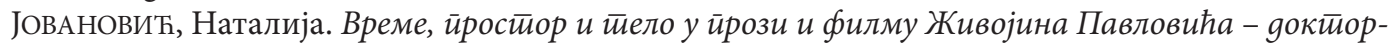
ска guсерйација. Београд, Филолошки факултет (JovANOvić, Natalija. Vreme, prostor i telo u prozi i filmu Živojina Pavlovića - doktorska disertacija. Beograd, Filološki fakultet), 2017.

КолАРИЋ, Владимир. „Естетичка схватања Живојина Павловића: О уметности и односу књижевности и филма.” (KolARIĆ, Vladimir. „Estetička shvatanja Živojina Pavlovića: O umetnosti i odnosu književnosti i filma.") Humanistika: časopis za istraživanja u društvenim i humanističkim naukama 1/2 (septembar 2017): 21-33. 
ЛујАк, Михаило. Промена йараяиімме архииекеионско-урбанистиччких кониейайа на објек-

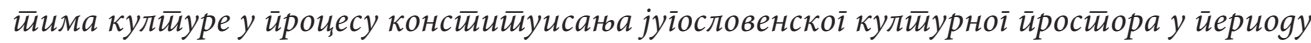
og 1947. go 1974 - gокйорска guсертиаиија. Београд: Архитектонски факултет (LUJAK, Mihailo. Promena paradigme arhitektonsko-urbanističkih koncepata na objektima kulture u procesu konstituisanja jugoslovenskog kulturnog prostora u periodu od 1947. do 1974 - doktorska disertacija. Beograd: Arhitektonski fakultet), 2012.

MARCONI, Clemente. "The Parthenon frieze - Degrees of visibility." RES: Anthropology and Aesthetics 55/56 (spring/autumn 2009): 156-173.

Osborne, Robin. "The Viewing and Obscuring of the Parthenon Frieze." Journal of Hellenic Studies vol. 107 (1987): 98-105.

Østermark-Johansen, Lene. "Frieze: Getting Beneath the Surface of the Past in Aestheticist Painting and Writing." Victorian Studies vol. 52, no. 1 (Autumn 2009): 20-31.

PAVlović, Živojin. Film u školskim klupama (Pledoaje i praktična uputstva za uvođenje filma u školu kao nastavnog predmeta). Beograd: $3 \mathrm{D}+$; Niš: Niški kulturni centar, 2010 (tekstovi prvobitno objavljeni 1956-58).

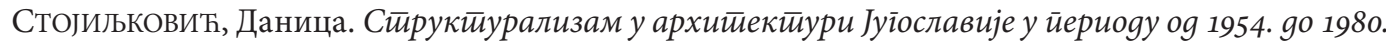

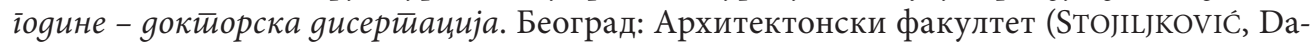
nica. Strukturalizam u arhitekturi Jugoslavije u periodu od 1954. do 1980. godine - doktorska disertacija. Beograd: Arhitektonski fakultet), 2017.

FEHR, Burkhard. Becoming Good Democrats and Wives. Civic Education and Female Socialization on the Parthenon Frieze. Wien, Zurich, Berlin, Munster: LIT Verlag, 2011

Sonja R. Jankov

\title{
FRIEZE AS A TEACHING DEVICE - CONTRIBUTION OF ŽIVOJIN PAVLOVIĆ TO ARCHITECTURE OF YUGOSLAV MODERNISM
}

\author{
Summary
}

The paper focuses on the frieze in the Faculty of Dramatic Arts building in Belgrade (1975), the only realized building of the planned urban unit for the University of Arts. The author of the frieze is Živojin Pavlović (1933-1998), the well-known black-wave film director who later became a full professor at the Faculty. As the frieze is composed only of images, the paper traces their origins and analyzes compositional segments concerning their contents and the architecture.

The frieze presents numerous inventions, including praxinoscope (1877) and optical theatre (1988) - inventions by Charles-Émile Reynaud, Edison's kinetoscope (1894), the Lumière cinématographe (1895), Étienne-Jules Marey's chronophotography (1882), Guitton de Giraudy automatic plate-changing camera (1895), téléoscope by François Dussaud (1898), Eadweard Muybridge's studies of horse in motion (1878), Gaumont's pocket camera (1900), George Clymer's classic Columbian press (1828), a miniature pocket typewriter Polyglotte (1878). It also features reproductions of engravings by Albrecht Dürer, Paul Gustav Doré, and works by leading calligraphers of their time, inserts from the history of theatre, and a couple of early concepts of flying machines. In addition, the frieze contains illustrations that clearly indicate gender equality. 
ФРИЗ КАО УЏБЕНИК: ДОПРИНОС ЖИВОЈИНА ПАВЛОВИЋА АРХИТЕКТУРИ ЈУГОСЛОВЕНСКОГ...

Despite its fragmented form caused by the specific Faculty building, the frieze shares some characteristics with the ancient frieze, such as the intention to educate, initiate movement, and engage a viewer in the interactive play of discovering its entire content, as well as to inspire students to create their own place in the history of presented disciplines. It represents an important contribution to the form of a frieze in the XX century, as well as to education about the film, theatre, and television thought at the Faculty of Dramatic Arts.

Keywords: frieze, Živojin Pavlović, Yugoslav architecture, Faculty of Dramatic Arts. 